\title{
Urotensin-II Contributes to Pulmonary Vasoconstriction in a Perinatal Model of Persistent Pulmonary Hypertension of the Newborn Secondary to Meconium Aspiration Syndrome
}

\author{
CATHERINE M. SIMPSON, JOSEPH J. SMOLICH, LARA S. SHEKERDEMIAN, AND DANIEL J. PENNY \\ Heart Research Group [C.M.S., J.J.S., L.S.S., D.J.P.], Murdoch Children's Research Institute, \\ Parkville, Victoria 3052, Australia; Departments of Cardiology and Intensive Care [L.S.S., D.J.P.], The Royal Children's Hospital, \\ Parkville, Victoria 3052, Australia; Department of Paediatrics [C.M.S., J.J.S., L.S.S., D.J.P.], The University of Melbourne, \\ Parkville, Victoria 3052, Australia
}

\begin{abstract}
Meconium aspiration syndrome (MAS) disrupts perinatal decreases in pulmonary vascular resistance (PVR) and is the commonest cause of neonatal pulmonary hypertension. The contribution of the potent vasoactive agent urotensin-II (U-II), in the pathophysiology of this condition, is unknown. In a new perinatal model of MAS, we combined measurement of circulating U-II levels with U-II receptor blockade studies. Nineteen anesthetized lambs were instrumented then randomly allocated to the following groups: 1) control $(n=5), 2)$ control plus specific U-II receptor blockade with palosuran $(n=5), 3)$ tracheal instillation of meconium $(n=5)$, 4) meconium instillation plus palosuran $(n=4)$. Hemodynamics, PVR, and plasma U-II were measured for $6 \mathrm{~h}$ after delivery. After birth in controls, U-II increased $(p<0.05)$, and PVR fell $(p=0.01)$ and this fall was prevented by U-II receptor blockade. By contrast, meconium lambs displayed a greater rise in U-II levels $(p<0.05$ versus control) with an increase in $\operatorname{PVR}(p<0.005)$ that was attenuated by U-II receptor blockade $(p<0.001)$. These findings suggest that U-II normally acts as a pulmonary vasodilator after birth, but in the presence of MAS, it assumes a vasoconstrictor role. U-II receptor blockade also improves pulmonary hemodynamics in this model. (Pediatr Res 67: 150-157, 2010)
\end{abstract}

$\mathrm{M}$ econium aspiration syndrome (MAS) is a severe neonatal respiratory disorder (1) and is the commonest cause of pulmonary hypertension of the newborn (PHN) (2). MAS disrupts the perinatal transition in the pulmonary circulation, so that, the usual fall in pulmonary artery pressure $\left(\mathrm{P}_{\mathrm{PA}}\right)$ and pulmonary vascular resistance (PVR), and increase in pulmonary artery blood flow $\left(\mathrm{Q}_{\mathrm{PA}}\right)$ are impeded. These abnormalities, in association with damage to lung parenchyma induced by aspirated meconium, may lead to critical hypoxemia and pulmonary hypertension (1-4).

Important knowledge regarding the pathophysiology of MAS has been obtained from animal models (1-4). However, a significant limitation of most existing models is that they have been performed in animals that are several days to weeks old and have already negotiated much of the perinatal transi-

Received June 3, 2009; accepted September 22, 2009.

Correspondence: Dan Penny, M.D., Ph.D., F.R.A.C.P., Department of Cardiology, The Royal Children's Hospital, Flemington Rd, Parkville, Victoria 3052, Australia; e-mail: dan.penny@rch.org.au

Supported by a postgraduate medical research scholarship from The National Health and Medical Research Council of Australia (to C.M.S.). This project was supported by a Grant-in-Aid from The National Heart Foundation of Australia. tion. This limits the investigation of fundamental early events in the pathophysiology of MAS.

Animal studies $(5,6)$, which are consistent with observations in humans (6), indicate that the fall in PVR after birth is dependent on the action of endothelium-related vasoregulators. An imbalance in these vasoregulators is a characteristic feature of PHN, with up-regulation of vasoconstrictor influences (6). The vasoconstrictor that has received greatest attention in MAS is endothelin-1 (ET-1). Circulating ET-1 levels parallel the rise in $\mathrm{P}_{\mathrm{PA}}$ (7) and PVR (7) and antagonism of the ET receptor lowers these variables $(2,8)$. However, as the hemodynamic abnormalities in MAS are not completely reversed by high doses of ET-receptor antagonists (2), it is clear that ET-1 is only one of a number of mediators in the pathophysiology of PHN in this setting.

A recently uncovered endothelial-derived vasoregulatory mediator is urotensin-II (U-II). U-II has potent vasodilator and vasoconstrictor actions and is synthesized in the pulmonary endothelium (9). Plasma and lung tissue homogenate levels of U-II $(10,11)$ and expression of U-II by pulmonary arterial endothelial and smooth muscle cells (12) are elevated in different models of pulmonary hypertension. However, the potential contribution of U-II to the perinatal transitional circulation, and in particular, to the pathogenesis of PHN is unknown.

Accordingly, the aim of this study was to investigate the potential role of U-II in the neonatal pulmonary transitional circulation, in the absence and presence of MAS, by examining the changes in plasma levels of U-II and the effects of palosuran, a specific antagonist of the U-II receptor (13).

\section{METHODS}

Experiments were approved by The Animal Ethics Committee of Murdoch Children's Research Institute.

Abbreviations: ABG, arterial blood gas; CI, cardiac index; ET-1, endothelin-1; $\mathbf{F i O}_{2}$, fractional inspired oxygen; MAS, meconium aspiration syndrome; OI, oxygenation index; $\mathbf{P}_{\mathbf{A o}}$, aortic pressure; $\mathbf{P}_{\mathbf{P A}}$, pulmonary artery pressure; PHN, pulmonary hypertension of the newborn; PVR, pulmonary vascular resistance; $\mathbf{Q}_{\mathbf{L P A}}$, left pulmonary artery blood flow; $\mathbf{Q}_{\mathbf{P A}}$, pulmonary artery blood flow; SVR, systemic vascular resistance; U-II, urotensin-II 
Experimental preparation. Nineteen Border-Leicester cross ewes (gestation, $139 \pm 2 \mathrm{~d}$, term $=147 \mathrm{~d}$ ) were anesthetized, intubated, and ventilated. $\mathrm{O}_{2}$ saturation $\left(\mathrm{SpO}_{2}\right)$ was monitored continuously with a pulse-oximeter (Tyco Healthcare; CA) applied to the ear. Polyvinyl catheters were inserted into the external jugular vein and the common carotid artery. Ventilation was adjusted to maintain arterial $\mathrm{PO}_{2}$ and $\mathrm{PCO}_{2}$ within physiologic ranges. Body temperature was maintained at $38-40^{\circ} \mathrm{C}$.

Fetal surgery. After delivery through a midline hysterotomy, the fetal head was placed in a warm saline-filled surgical glove. Polyvinyl catheters were advanced through the external jugular vein into the right atrium and through the common carotid artery into the ascending aorta. Arterial blood gas (ABG) samples were taken every $30 \mathrm{~min}$.

After partial exteriorization of the fetus, the heart and great vessels were exposed through a left thoracotomy. A catheter was inserted into the left atrium for pressure measurement. A 10 - to $14-\mathrm{mm}$ diameter perivascular ultrasonic flow probe (model 10A-14A Transonic Systems; NY) was placed around the pulmonary trunk to measure $\mathrm{Q}_{\mathrm{PA}}$ and, after closure of the DA, cardiac output. A 4- to 6-mm diameter ultrasonic flow probe (model 4S-6S; Transonic Systems) was placed around the left pulmonary artery to measure left lung flow $\left(\mathrm{Q}_{\mathrm{LPA}}\right)$ and to calculate PVR. An additional catheter was inserted into the pulmonary trunk distal to the flow probe. The skin edges of the thoracic incision were closed with tissue forceps.

Study groups. Lambs were randomly allocated to one of four groups. The control group $(n=5)$ received routine monitoring and intensive care only. The palosuran group $(n=5)$ additionally received a continuous infusion of the specific U-II receptor antagonist, palosuran $\left(10 \mathrm{mg} \cdot \mathrm{kg}^{-1} \cdot \mathrm{h}^{-1}\right.$; Actelion Pharmaceuticals, Switzerland), commenced immediately after delivery and continued until the end of the experiment. The infusion rate was chosen according to previous studies (13) and pilot studies in newborn lambs, which demonstrated that this dose was well tolerated. The meconium group $(n=5)$ received $3 \mathrm{~mL} / \mathrm{kg}$ of filtered $20 \%$ human meconium (1), instilled deeply into the trachea, and upper airways immediately after delivery. The meconiumpalosuran group $(n=4)$ received both meconium and a palosuran infusion.

Delivery of lamb. After intubation of the fetal trachea, lung liquid was drained under gravity to enhance gas exchange, and the endotracheal tube was clamped to prevent lung aeration. The lamb was delivered onto a heated resuscitation table, and the umbilical cord was clamped and cut. After withdrawal of umbilical cord blood for replacement of volume in the lamb during subsequent blood sampling, the ewe was euthanized.

After delivery, control and palosuran animals received two manual chest inflations with a fractional inspired oxygen $\left(\mathrm{FiO}_{2}\right)$ of $1.0 \%$, in the left lateral and then right lateral position. Meconium and meconium-palosuran animals also received two manual inflations, each preceded by instillation of half the total amount of meconium. Mechanical ventilation was commenced using a time-cycled, pressure-limited mode (Infant Star 500; Infrasonics, CA). For the control and palosuran groups, initial ventilator settings were a peak inspiratory pressure of $30 \mathrm{~cm} \mathrm{H}_{2} \mathrm{O}$, a positive end expiratory pressure of $4 \mathrm{~cm} \mathrm{H}_{2} \mathrm{O}$, a respiratory rate of 30/min, inspiratory time of $1.0 \mathrm{~s}$, and $\mathrm{FiO}_{2}$ of 0.3 . Pilot studies indicated that a higher degree of ventilation was required early after meconium administration, so the initial ventilator settings in the meconium and meconium-palosuran groups were a peak inspiratory pressure of 35 $\mathrm{cmH}_{2} \mathrm{O}$, a positive end expiratory pressure of $6 \mathrm{cmH}_{2} \mathrm{O}$, a respiratory rate of $35 / \mathrm{min}$, inspiratory time of $0.8 \mathrm{~s}$, and $\mathrm{FiO}_{2}$ of 0.8 .

Anesthesia was maintained with continuous infusions of ketamine (4 $\left.\mathrm{mg} \cdot \mathrm{kg}^{-1} \cdot \mathrm{h}^{-1}\right)$ and midazolam $\left(0.05 \mathrm{mg} \cdot \mathrm{kg}^{-1} \cdot \mathrm{h}^{-1}\right)$, and i.v. maintenance fluid was given. $\mathrm{SpO}_{2}$ was monitored continuously with a pulse-oximeter applied to the cheek, and $\mathrm{ABG}$ analysis was performed frequently. $\mathrm{FiO}_{2}$ was adjusted to maintain arterial hemoglobin $\mathrm{O}_{2}>95 \%$ (14). Ventilation was adjusted to maintain $\mathrm{PCO}_{2}$ at $40-45 \mathrm{~mm} \mathrm{Hg}$. Body temperature was maintained within physiologic limits $\left(38 \pm 0.1^{\circ} \mathrm{C}\right)$.

After a 15-min period of stabilization, initial baseline recording of hemodynamic variables and aortic blood gas analysis was performed. Subsequently, hemodynamic data were recorded, and aortic and pulmonary arterial blood samples were collected at $30 \mathrm{~min}$ intervals until $2 \mathrm{~h}$ and then hourly thereafter. As the DA normally closes very rapidly in lambs (15), it was occluded with a vascular clamp after the 1-h measurement, to remove the potentially confounding effect of any shunting on hemodynamics and blood gases.

After $6 \mathrm{~h}$, lambs were euthanized and body and lung weights were recorded.

U-II and ET-1 assays. Pulmonary arterial blood samples were centrifuged at $4^{\circ} \mathrm{C}$ and $3000 \mathrm{rpm}$ for $10 \mathrm{~min}$. Plasma was stored at $-80^{\circ} \mathrm{C}$, and later analyzed for U-II and ET-1 by RIA $(16,17)$.

Physiologic variables. Vascular pressures were measured via transducers (Transpac IV, Abott Critical Care Systems, Ireland) referenced to atmospheric pressure at the level of the left atrium. Pressure signals were processed with a transducer amplifier (Transbridge TBM4M; World Precision Instruments, FL). Flows were measured with a flowmeter (model T206; Transonic Systems, NY). Physiologic signals were digitized at a rate of $1000 \mathrm{~Hz}$ and stored on computer using an analogue-to-digital converter (iNet-100B; GW Instruments, MA) interfaced with programmable acquisition and analysis software (Spike2; Cambridge Electronic Design, UK). A 48-Hz low-pass filter was applied during analysis to remove electrical interference.

ABG samples were measured with a blood gas analyser (Radiometer ABL 620; Denmark). PVR of the left lung was calculated as: $\mathrm{PVR}=$ mean $\mathrm{P}_{\mathrm{PA}}$ $(\mathrm{mm} \mathrm{Hg})-$ mean $\mathrm{P}_{\mathrm{LA}}(\mathrm{mm} \mathrm{Hg}) /$ mean $\mathrm{Q}_{\mathrm{LPA}}(\mathrm{mL} / \mathrm{min})$, where $\mathrm{P}_{\mathrm{LA}}=$ left atrial pressure, and was normalized to $100 \mathrm{~g}$ of lung weight. Systemic vascular resistance (SVR) was calculated after closure of the ductus arteriosus as: $\mathrm{SVR}=$ mean $\mathrm{P}_{\mathrm{Ao}}(\mathrm{mm} \mathrm{Hg})-$ mean $\mathrm{P}_{\mathrm{RA}}(\mathrm{mm} \mathrm{Hg}) /$ mean $\mathrm{Q}_{\mathrm{PA}}, \mathrm{mL} / \mathrm{min}$, where $\mathrm{P}_{\mathrm{Ao}}=$ aortic pressure and $\mathrm{P}_{\mathrm{RA}}=$ right atrial pressure, and normalized to body weight. Cardiac index (CI) was calculated using $\mathrm{Q}_{\mathrm{PA}}$ after ductal closure (cardiac output) and indexed to body weight. Oxygenation index (OI) was calculated as mean airway pressure $\times \mathrm{FiO}_{2} \times 100 / \mathrm{PO}_{2}$.

Statistical analysis. Data were analyzed with SigmaStat for Windows (v3.0; San Jose, CA), using one- and two-way ANOVA. Posthoc analysis to look for specific effects within group variables was performed by partitioning the sums of squares into individual degrees of freedom (18). Posthoc analysis of between group variables was performed using the Bonferroni correction. Results are expressed as mean \pm SEM, with $p<0.05$ considered statistically significant.

\section{RESULTS}

Baseline variables. Pulmonary hemodynamic variables, OI and plasma U-II and ET-1 levels were similar in all groups. Compared with controls, CI tended to be lower in the meconium group $(p=0.08)$ and was lower in the meconiumpalosuran group $(p<0.05)$. Baseline SVR was lower in the palosuran group $(p<0.05$; Table 1$)$.

Effect of meconium aspiration. Between 15 and $360 \mathrm{~min}$ after birth, $\mathrm{P}_{\mathrm{PA}}$ fell progressively in controls $(p<0.001)$ but

Table 1. Baseline variables in all study groups

\begin{tabular}{|c|c|c|c|c|}
\hline Baseline measure & $\begin{array}{l}\text { Control } \\
\text { group }\end{array}$ & $\begin{array}{l}\text { Palosuran } \\
\text { group }\end{array}$ & $\begin{array}{l}\text { Meconium } \\
\text { group }\end{array}$ & $\begin{array}{c}\text { Meconium-Palosuran } \\
\text { group }\end{array}$ \\
\hline $\mathrm{P}_{\mathrm{PA}}(\mathrm{mm} \mathrm{Hg})$ & $49(4)$ & $41(4)$ & $44(3)$ & $49(5)$ \\
\hline $\mathrm{Q}_{\mathrm{LPA}}\left(\mathrm{mL} \times \min ^{-1} \times 100 \mathrm{~g}^{-1}\right)$ & $1201(170)$ & $1149(225)$ & $907(61)$ & $1065(96)$ \\
\hline Left lung PVR $\left(\mathrm{mm} \mathrm{Hg} \times \mathrm{mL}^{-1} \times \min ^{-1} \times 100 \mathrm{~g}^{-1}\right)$ & $0.037(0.01)$ & $0.031(0.006)$ & $0.039(0.002)$ & $0.036(0.003)$ \\
\hline Oxygenation index & $10(3)$ & $7(2)$ & $11(2)$ & $13(5)$ \\
\hline $\mathrm{P}_{\mathrm{Ao}}(\mathrm{mm} \mathrm{Hg})$ & $66(3)$ & $55(6)$ & $63(3)$ & $70(7)$ \\
\hline Cardiac Index $\left(\mathrm{mL} \mathrm{min}^{-1} \times \mathrm{kg}^{-1}\right)$ & $198(8)$ & $183(14)$ & $153(18)$ & $136(10)^{*}$ \\
\hline $\operatorname{SVR}\left(\mathrm{mm} \mathrm{Hg} \mathrm{mL} L^{-1} \min ^{-1} \times \mathrm{kg}^{-1}\right)$ & $0.33(0.01)$ & $0.23(0.03)^{*}$ & $0.33(0.04)$ & $0.4(0.04)$ \\
\hline U-II (pmol/L) & $1.28(0.1)$ & $1.2(0.1)$ & $1.43(0.12)$ & $1.53(0.05)$ \\
\hline ET-1 (pmol/L) & $8.1(0.6)$ & $14.2(1.8)$ & $11.7(1.3)$ & $10.5(2.6)$ \\
\hline
\end{tabular}

Mean (SEM) hemodynamic variables, Oxygenation Index, U-II and ET-1 levels at first post-natal measure. The ductus arteriosus was occluded after the 60 min measurement. Note that Cardiac Index and SVR were first obtained at the 90 min time-point.

$* p<0.05$ compared with control group. 

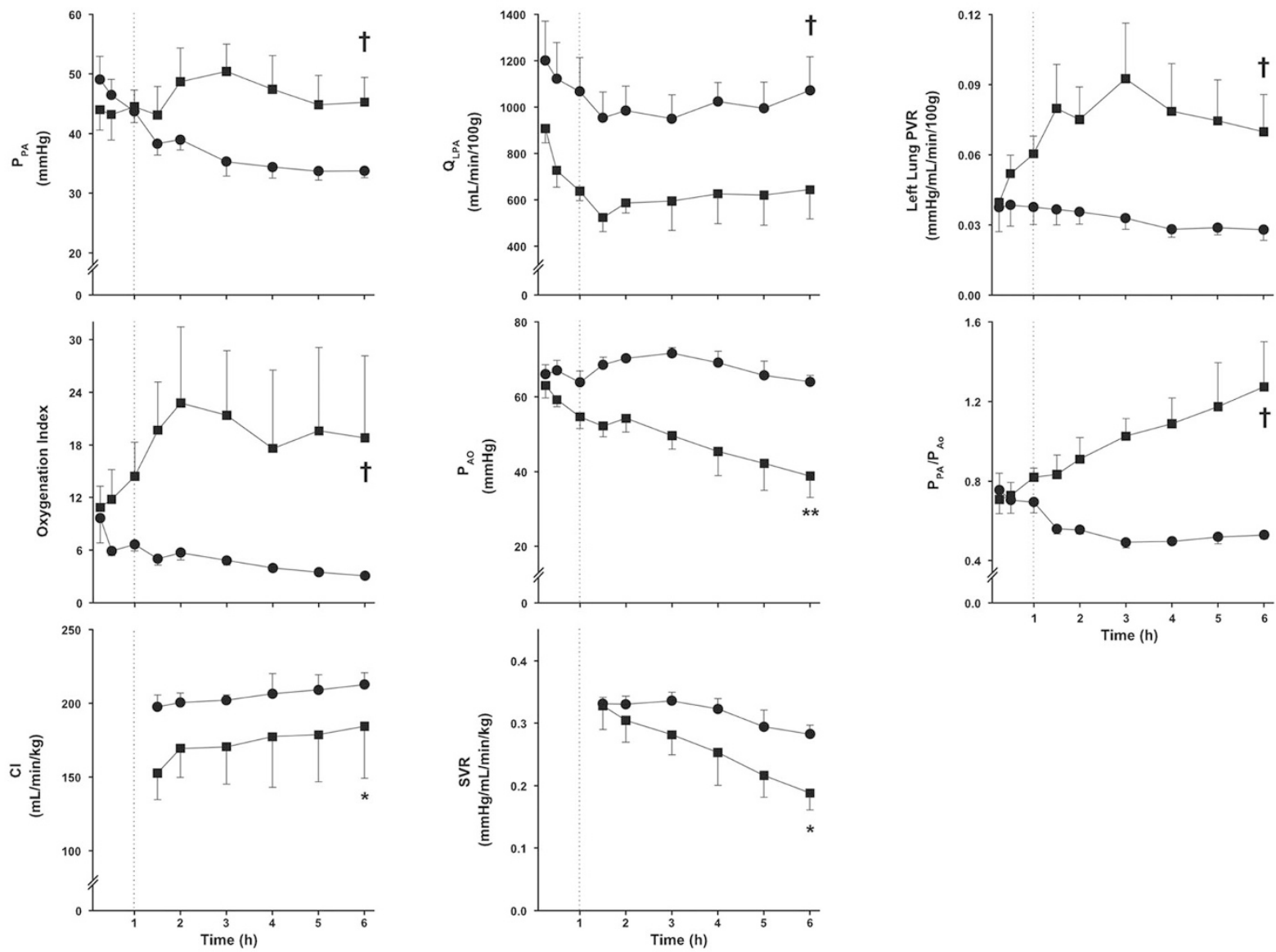

Figure 1. Hemodynamic variables and $\mathrm{OI}$ in $\operatorname{control}(\boldsymbol{\bullet}, n=5)$ and meconium $(\boldsymbol{\square}, n=5)$ groups. The dotted line at $1 \mathrm{~h}$ indicates the time of ductal occlusion. Results are expressed as mean \pm SEM. ${ }^{*} p<0.05,{ }^{* *} p<0.01, \dagger p<0.001$ (between groups).

was unchanged in the meconium group. $\mathrm{Q}_{\mathrm{LPA}}$ fell in both controls and meconium animals $(p<0.005$ for both) but remained higher in controls throughout the study period. Thus, although PVR fell progressively in controls $(p=0.01)$, it increased in the meconium group $(p<0.005)$. OI also fell progressively in controls $(p<0.001)$ but increased in the meconium group $(p<0.01)$ (Fig. 1).

$\mathrm{P}_{\text {Ao }}$ was unchanged over the study period in controls, but fell in the meconium group $(p<0.005)$. As a result, the ratio between $\mathrm{P}_{\mathrm{PA}}$ and $\mathrm{P}_{\mathrm{Ao}}$ fell in controls $(p<0.001)$ but increased in animals receiving meconium $(p<0.01)$ (Fig. 1).

After ductal closure, CI was maintained in both groups but was higher in controls compared with the meconium group. SVR fell in both $(p<0.05$ for controls; $p<0.001$ for meconium), although the fall was greater in the meconium group (Fig. 1).

Arterial $\mathrm{pH}, \mathrm{Po}_{2}, \mathrm{Pco}_{2}, \mathrm{SaO}_{2}$, and $\mathrm{Fio}_{2}$ did not change between 15 and 360 min after birth in controls; however, in meconium animals, $\mathrm{Po}_{2}$ and $\mathrm{SaO}_{2}$ fell significantly during this time. Over the whole observation period, $\mathrm{pH}$ and $\mathrm{SaO}_{2}$ were significantly lower in meconium animals, compared with controls, whereas $\mathrm{PcO}_{2}$ and $\mathrm{Fio}_{2}$ were higher (Table 2).

During the study period, U-II levels increased in the control $(p<0.05)$ and meconium groups $(p<0.001)$ with the increase being greater in the latter. ET-1 levels were un- changed in controls but increased in the meconium animals $(p<0.025)$ (Fig. 2).

Effects of palosuran in the absence of meconium. The fall in $\mathrm{P}_{\mathrm{PA}}$ that occurred during the study period in controls was not altered by palosuran. However, palosuran resulted in an exaggerated fall in $\mathrm{Q}_{\mathrm{LPA}}$, so that the reduction in left lung PVR in controls was abolished by palosuran. Although the difference in PVR between control and palosuran groups was small, when analyzed in terms of percent change from baseline to $6 \mathrm{~h}$, PVR in controls had fallen by $17 \%$ and in palosuran animals had increased by 24\% $(p<0.001$ for difference between groups).

OI initially increased in palosuran animals $(p<0.01)$, so that over the duration of the study, OI was greater in the palosuran group. $\mathrm{P}_{\mathrm{Ao}}$ was unchanged over the study period in controls but fell in the palosuran group $(p<0.001)$. As a result the ratio of $\mathrm{P}_{\mathrm{PA}} / \mathrm{P}_{\mathrm{Ao}}$, which fell in controls increased in the palosuran group $(p<0.001)$. After ductal closure, CI was maintained in controls, but tended to fall in the palosuran group $(p=0.06)$, so that over the duration of the study, CI was lowered by palosuran. After ductal closure, SVR fell in controls $(p<0.05)$, and palosuran-treated animals $(p<$ 0.001) but was lower in the palosuran group (Fig. 3).

In the palosuran group, $\mathrm{pH}, \mathrm{PcO}_{2}$ and $\mathrm{Fio}_{2}$ did not change significantly between 15 and $360 \mathrm{~min}$ after birth, whereas $\mathrm{Po}_{2}$ fell 
Table 2. Arterial blood gases and inspired oxygen fraction in all study groups over time

\begin{tabular}{|c|c|c|c|c|c|c|c|c|c|c|c|c|c|}
\hline \multirow[b]{2}{*}{ Time (h) } & \multirow[b]{2}{*}{0.25} & \multirow[b]{2}{*}{0.5} & \multirow[b]{2}{*}{1} & \multirow[b]{2}{*}{1.5} & \multirow[b]{2}{*}{2} & \multirow[b]{2}{*}{3} & \multirow[b]{2}{*}{4} & \multirow[b]{2}{*}{5} & \multirow[b]{2}{*}{6} & \multicolumn{4}{|c|}{$p$} \\
\hline & & & & & & & & & & $\begin{array}{l}\text { Within } \\
\text { group }\end{array}$ & $\begin{array}{c}\text { Control } \\
\text { vs } \\
\text { Pal }\end{array}$ & $\begin{array}{c}\text { Control } \\
\text { vs } \\
\mathrm{Mec}\end{array}$ & $\begin{array}{c}\text { Mec vs } \\
\text { Mec-Pal }\end{array}$ \\
\hline $\mathrm{pH}$ & & & & & & & & & & & & & \\
\hline Control & $7.30(0.04)$ & $7.37(0.02)$ & $7.40(0.04)$ & $7.38(0.04)$ & $7.35(0.03)$ & $7.35(0.04)$ & $7.39(0.03)$ & $7.34(0.03)$ & $7.32(0.02)$ & N.S. & & & \\
\hline Pal & $7.30(0.05)$ & $7.30(0.05)$ & $7.30(0.03)$ & $7.28(0.02)$ & $7.29(0.02)$ & $7.31(0.03)$ & $7.31(0.03)$ & $7.28(0.01)$ & $7.27(0.02)$ & N.S. & $<0.001$ & & \\
\hline Mec & $7.23(0.04)$ & $7.30(0.02)$ & $7.31(0.03)$ & $7.27(0.03)$ & $7.26(0.03)$ & $7.24(0.02)$ & $7.27(0.04)$ & $7.28(0.05)$ & $7.28(0.04)$ & N.S. & & $<0.001$ & \\
\hline Mec-Pal & $7.20(0.05)$ & $7.31(0.06)$ & $7.36(0.06)$ & $7.31(0.05)$ & $7.24(0.02)$ & $7.21(0.04)$ & $7.24(0.02)$ & $7.24(0.02)$ & $7.22(0.01)$ & $<0.05$ & & & N.S. \\
\hline \multicolumn{14}{|c|}{ 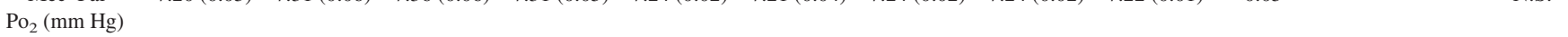 } \\
\hline Control & $101(28)$ & $106(21)$ & $67(5)$ & $64(3)$ & $64(5)$ & $77(8)$ & $88(9)$ & $85(8)$ & $89(6)$ & N.S. & & & \\
\hline Pal & 84 (14) & $63(9)$ & $52(4)$ & $45(2)$ & $61(7)$ & 75 (13) & $68(12)$ & $75(9)$ & $65(6)$ & $<0.05$ & 0.05 & & \\
\hline $\mathrm{Mec}$ & 147 (23) & $115(24)$ & $64(7)$ & $54(9)$ & $52(5)$ & $63(9)$ & 88 (13) & 77 (10) & $73(10)$ & $<0.001$ & & N.S. & \\
\hline Mec-Pal & $153(48)$ & $123(23)$ & 87 (12) & $75(15)$ & $72(11)$ & $58(4)$ & $61(5)$ & $60(3)$ & $65(7)$ & 0.01 & & & N.S. \\
\hline \multicolumn{14}{|c|}{$\mathrm{PcO}_{2}(\mathrm{~mm} \mathrm{Hg})$} \\
\hline Control & $45.4(6)$ & $37.3(2)$ & $33.6(2)$ & $37.1(2)$ & $40.5(1)$ & $40.9(3)$ & $37.3(2)$ & $41.3(2)$ & $43.1(1)$ & N.S. & & & \\
\hline $\mathrm{Pal}$ & $45.6(9)$ & $42.6(8)$ & $41.2(5)$ & $44.3(5)$ & $42.3(4)$ & $41.9(2)$ & $42.5(3)$ & $44.7(1)$ & $45.6(2)$ & N.S. & N.S. & & \\
\hline Mec & $53.9(7)$ & $42.9(3)$ & $39.6(1)$ & $46.6(2)$ & $51.4(4)$ & $49.1(0.5)$ & $46.8(5)$ & $46.5(7)$ & $45.3(6)$ & N.S. & & $<0.005$ & \\
\hline Mec-Pal & $59.8(9)$ & $43.8(9)$ & $35.2(7)$ & $35.7(3)$ & $43.5(2)$ & $54.3(7)$ & $46.8(4)$ & $46.5(4)$ & $47.3(3)$ & 0.01 & & & N.S. \\
\hline \multicolumn{14}{|c|}{$\mathrm{SaO}_{2}(\mathrm{~mm} \mathrm{Hg})$} \\
\hline Control & $98(2)$ & $99(0.4)$ & $99(0.4)$ & $98(0.2)$ & $97(0.3)$ & $99(0.4)$ & $99(1)$ & $98(1)$ & $99(1)$ & N.S. & & & \\
\hline Pal & $99(0.4)$ & $98(1)$ & $96(2)$ & $95(1)$ & $98(1)$ & $98(1)$ & $97(1)$ & $98(1)$ & $97(1)$ & N.S. & N.S. & & \\
\hline $\mathrm{Mec}$ & $100(0.2)$ & $99(1)$ & 97 (1) & $92(3)$ & $91(5)$ & $93(3)$ & $95(5)$ & $92(6)$ & $90(7)$ & $<0.01$ & & $<0.005$ & \\
\hline Mec-Pal & $97(2)$ & $96(3)$ & $96(4)$ & $97(1)$ & 97 (1) & $95(2)$ & $97(1)$ & $96(1)$ & $97(1)$ & N.S. & & & N.S. \\
\hline \multicolumn{14}{|l|}{$\mathrm{FiO}_{2}$} \\
\hline Control & $0.46(0.07)$ & $0.40(0.06)$ & $0.33(0.02)$ & $0.33(0.03)$ & $0.32(0.03)$ & $0.33(0.03)$ & $0.32(0.02)$ & $0.30(0.02)$ & $0.29(0.01)$ & N.S. & & & \\
\hline Pal & $0.36(0.05)$ & $0.34(0.07)$ & $0.39(0.08)$ & $0.45(0.07)$ & $0.53(0.06)$ & $0.52(0.06)$ & $0.52(0.09)$ & $0.56(0.10)$ & $0.59(0.14)$ & N.S. & 0.01 & & \\
\hline Mec & $0.71(0.08)$ & $0.59(0.06)$ & $0.45(0.04)$ & $0.50(0.05)$ & $0.60(0.11)$ & $0.64(0.12)$ & $0.63(0.13)$ & $0.62(0.13)$ & $0.60(0.13)$ & N.S. & & $<0.001$ & \\
\hline Mec-Pal & $0.73(0.11)$ & $0.68(0.10)$ & $0.59(0.14)$ & $0.50(0.16)$ & $0.51(0.16)$ & $0.54(0.16)$ & $0.53(0.16)$ & $0.54(0.16)$ & $0.59(0.14)$ & N.S. & & & N.S. \\
\hline
\end{tabular}

Values are expressed as mean (SEM).

Pal, palosuran; Mec, meconium; Mec-Pal, meconium-palosuran; N.S., not significant.
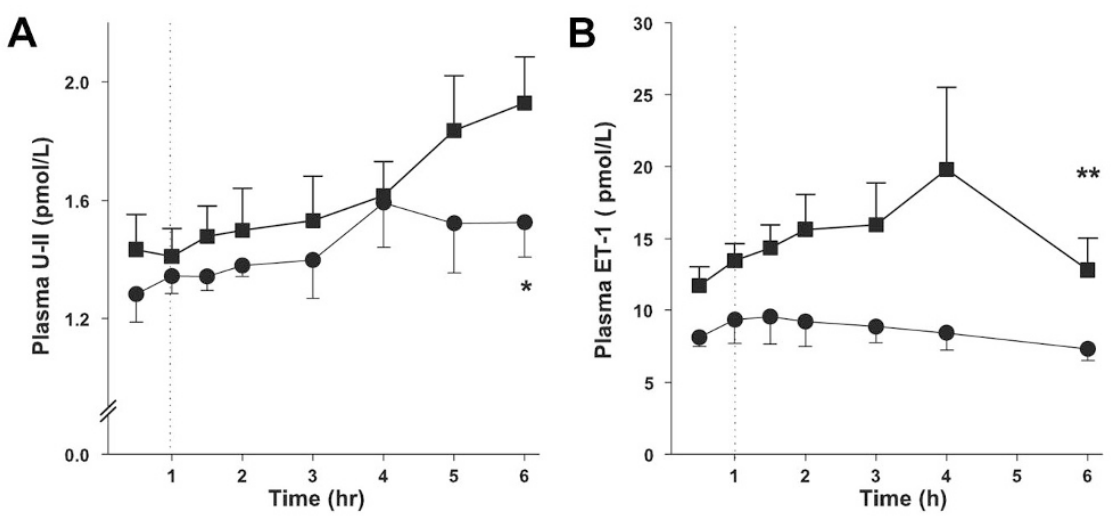

Figure 2. Plasma U-II $(A)$ and ET-1 $(B)$ in control $(\bullet, n=5)$ and meconium $(\boldsymbol{\square}, n=5)$ groups. The dotted line at $1 \mathrm{~h}$ indicates the time of ductal occlusion. Results are expressed as mean \pm SEM. $* p<0.05$, ** $p<0.01, \dagger p<$ 0.001 (between groups).
(Table 2). As a result, over the whole study period, $\mathrm{Po}_{2}$ was significantly lower in palosuran animals, compared with controls. Furthermore, a tendency toward a reduction in $\mathrm{pH}$ and an increase in $\mathrm{Fio}_{2}$ in palosuran animals resulted in a lower $\mathrm{pH}$ and a higher $\mathrm{FiO}_{2}$ in this group, compared with controls (Table 2).

The increase in U-II that occurred in controls was not altered by palosuran. ET-1 was unchanged in controls but tended to increase during the first postnatal hour in palosuran animals $(p=0.07)$ to levels that were significantly greater than controls beyond this time $(p<0.001)$ (Fig. 4).

Effects of palosuran after meconium aspiration. Between 15 and 360 min after birth, mean $\mathrm{P}_{\mathrm{PA}}$ was unchanged in the meconium group but fell in the meconium-palosuran group $(p<0.001), \mathrm{Q}_{\mathrm{LPA}}$ was similar in both groups throughout the study. Thus, although PVR increased in the meconium and meconium-palosuran animals ( $p<0.005$ for both), this increase was significantly attenuated in the latter. By contrast, the increase in OI in the meconium animals was not altered by palosuran (Fig. 5).
The fall in $\mathrm{P}_{\text {Ao }}$ was similar in the meconium and meconiumpalosuran animals, but the differences in pulmonary vascular responses between the two groups resulted in an attenuated increase in $\mathrm{P}_{\mathrm{PA}} / \mathrm{P}_{\mathrm{Ao}}$ in the meconium-palosuran group, compared with the meconium group. After ductal closure, CI was maintained in both meconium and meconium-palosuran groups, and similar falls in SVR occurred in both ( $p<0.001$ for both) (Fig. 5).

ABG variables were similar throughout the study in meconium and meconium-palosuran animals (Table 2).

The postnatal increase in U-II and ET-1 that occurred in the meconium group was not altered by palosuran (Fig. 6).

\section{DISCUSSION}

This study has provided two new findings. First, the normal fall in PVR in the initial hours after birth occurred in association with a rise in plasma U-II and was prevented by competitive antagonism of the U-II receptor. Second, a postnatal rise in PVR after MAS occurred in association with a greater 

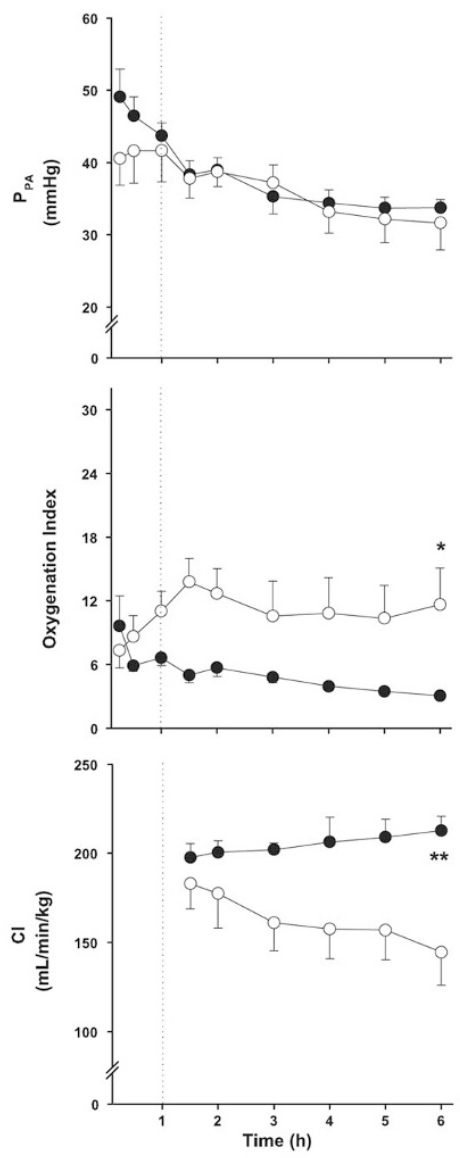
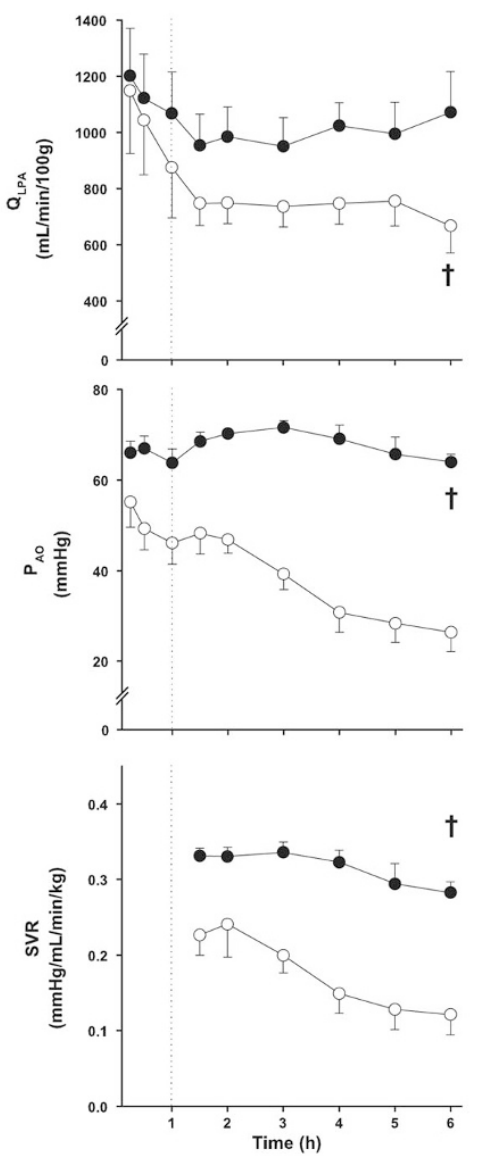
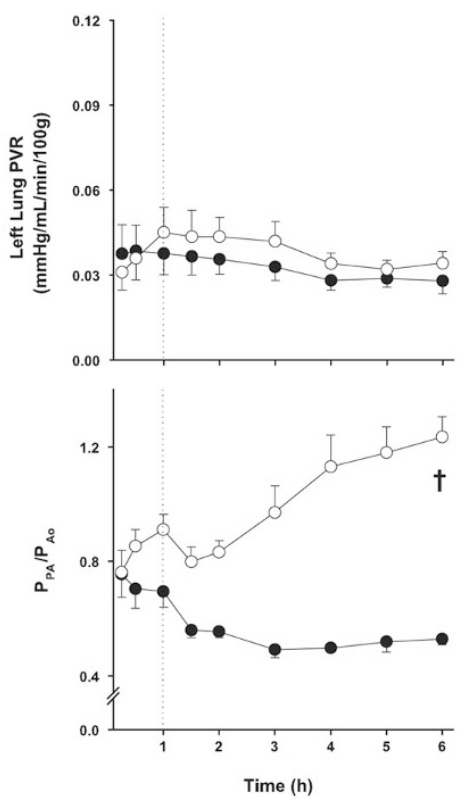

Figure 3. Hemodynamics and $\mathrm{OI}$ in control $(\bullet, n=5)$ and palosuran $(\bigcirc, n=5)$ groups. The dotted line at $1 \mathrm{~h}$ indicates the time of ductal occlusion. Results are expressed as mean \pm SEM. ${ }^{*} p<0.05,{ }^{* *} p<0.01, \dagger p<0.001$ (between groups).
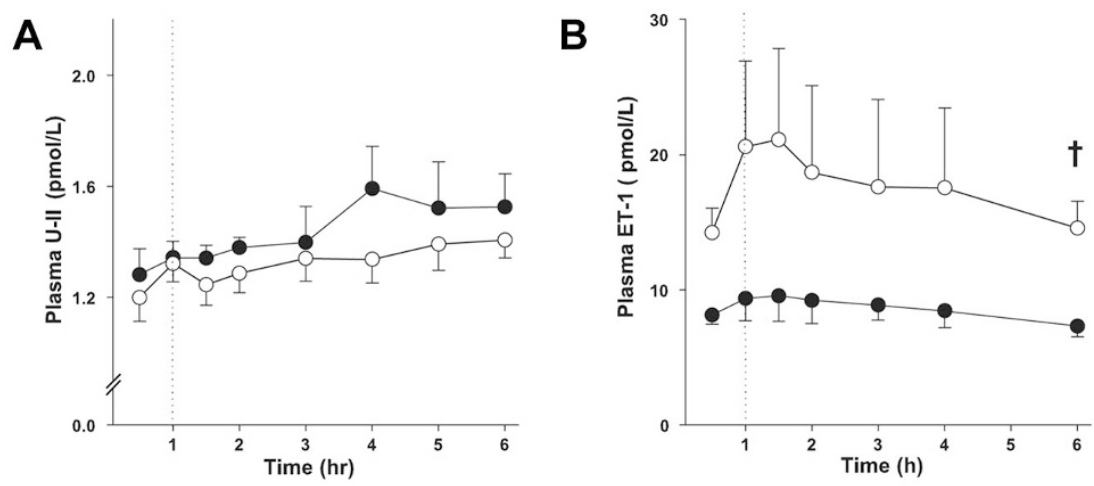

Figure 4. Plasma U-II $(A)$ and ET-1 $(B)$ in control $(\bullet, n=5)$ and palosuran $(\bigcirc, n=5)$ groups. The dotted line at $1 \mathrm{~h}$ indicates the time of ductal occlusion. Results are expressed as mean \pm SEM. $* p<0.05, * * p<0.01, \dagger p<$ 0.001 (between groups).

rise in U-II levels and was attenuated by antagonism of the U-II receptor.

This study has examined for the first time, the role of U-II in the first hours of life. We have shown that the normal fall in PVR was associated with an increase in U-II. This observation combined with the finding that antagonism of the U-II receptor with palosuran prevented the fall in PVR after birth suggests that U-II-mediated vasodilation contributes to the neonatal reduction in PVR. This hypothesis is consistent with some of the known properties of U-II (19), which are likely to be mediated at least in part through its interaction with specific endothelial receptors (20), resulting in the formation of nitric oxide, prostanoids, and endothelial-derived hyperpolarizing factor $(11,20-22)$.

Palosuran also produced a striking effect on the systemic circulation with the reduction in $\mathrm{P}_{\mathrm{Ao}}$ suggesting that U-II mediated systemic vasoconstriction may contribute to the maintenance of systemic arterial pressure in the neonatal period.

Our novel transnatal model of MAS closely resembled the human condition, with elevations in PVR and $\mathrm{P}_{\mathrm{PA}}$ and a reduction in $\mathrm{Q}_{\mathrm{PA}}$, alongside an increased OI. By the end of the study, $\mathrm{P}_{\mathrm{PA}}$ was supra-systemic, reproducing the findings in the clinical setting (23). This differs from previous models of 

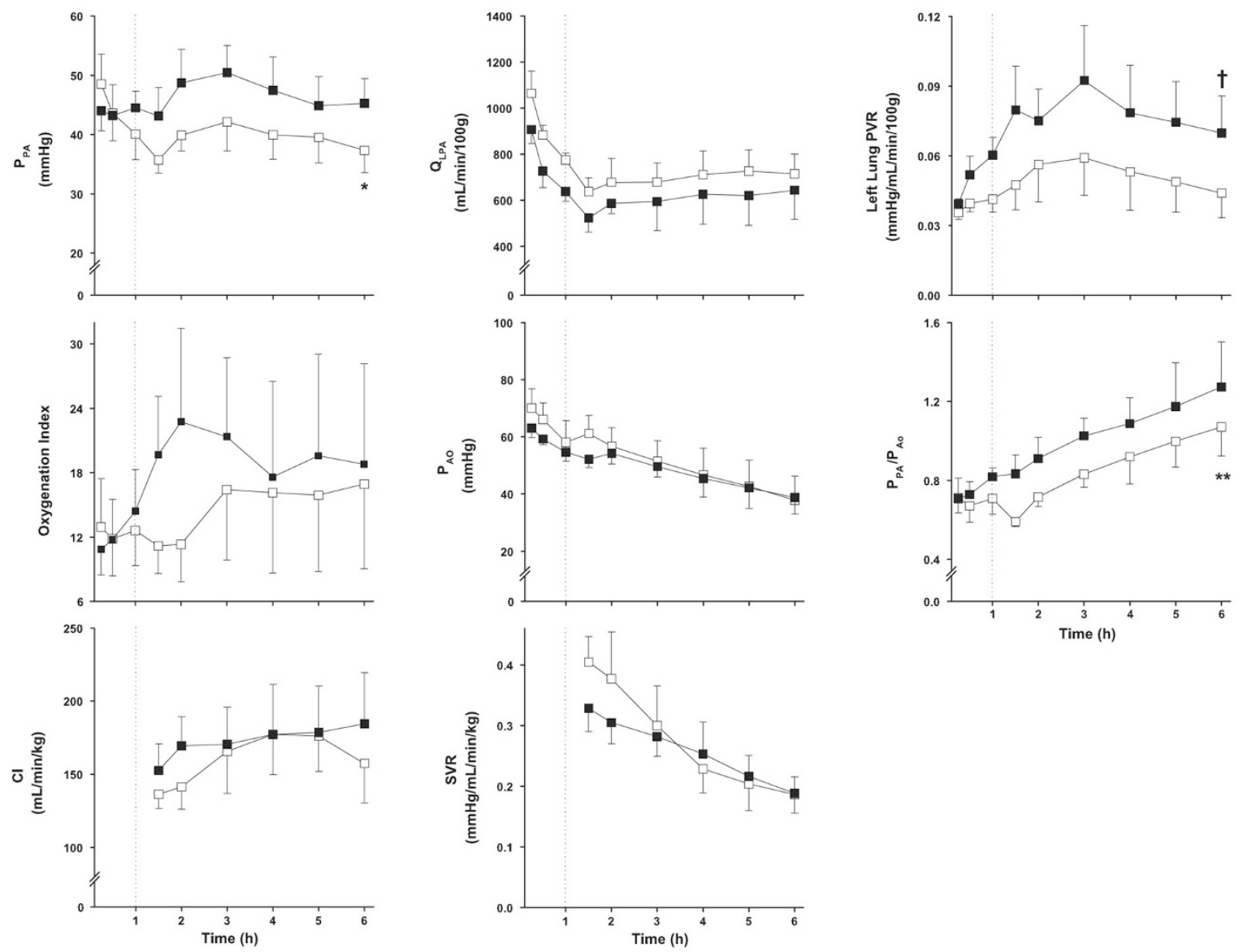

Figure 5. Hemodynamics and OI in meconium $(\boldsymbol{\square}, n=5)$ and meconium-palosuran $(\square, n=4)$ groups. The dotted line at $1 \mathrm{~h}$ indicates the time of ductal occlusion. Results are expressed as mean \pm SEM. ${ }^{*} p<0.05,{ }^{*} p<0.01, \dagger p<0.001$ (between groups).
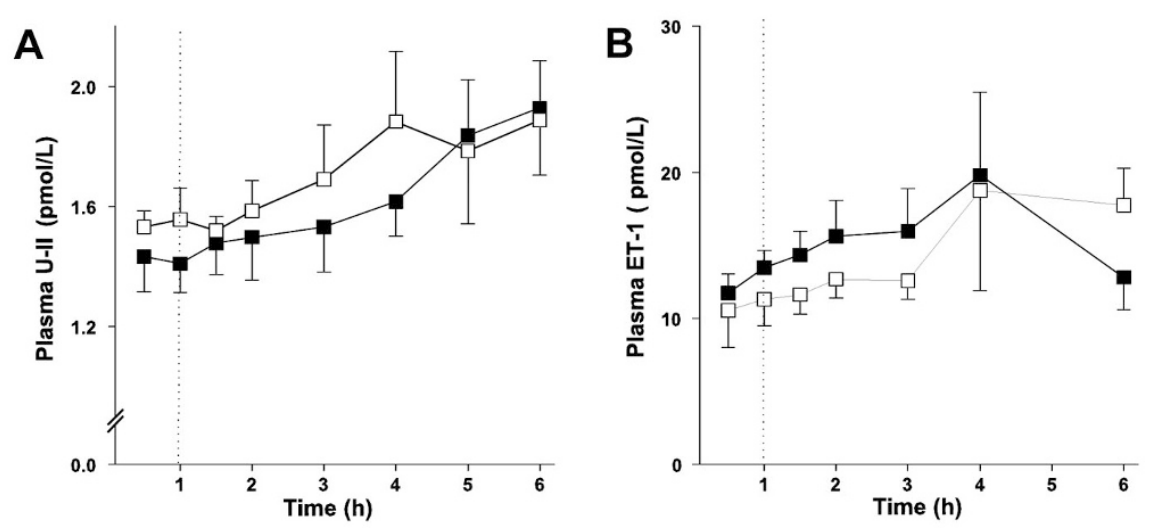

Figure 6. Plasma U-II $(A)$ and ET-1 $(B)$ in meconium $(\boldsymbol{\square}, n=5)$, and meconium-palosuran $(\square, n=4)$ groups. The dotted line at $1 \mathrm{~h}$ indicates the time of ductal occlusion. Results are expressed as mean \pm SEM. ${ }^{*} p<0.05$ $* * p<0.01, \dagger p<0.001$ (between groups).

meconium aspiration in more mature animals, which have already negotiated the perinatal transition, with pulmonary pressures peaking at only around a half of systemic $(1,5)$. In one of the few models in the literature to examine, the impact of meconium on the transitional circulation before the animal taking its first breath, PHN failed to develop in neonatal baboons (24). However, in this model, the crucial early postnatal hours were not examined, and $\mathrm{Q}_{\mathrm{PA}}$ and PVR were not measured. Moreover, only three animals were studied in the meconium group, with right ventricular systolic pressures tending to be higher than in controls.
In our model, we observed that the detrimental effects of meconium aspiration evolved over the first three postnatal hours, before reaching a plateau. This time course was similar to that observed in existing models of MAS (1), and to the clinical setting, when some neonates who may appear well immediately after birth, subsequently decompensate (25). We also demonstrated other features of MAS that are typical in the clinical setting. These included a fall in $\mathrm{P}_{\text {Ao }}$ (4) and acute parenchymal lung disease leading to ventilation-perfusion mismatch, arterial hypoxemia, acidosis, and an increased OI $(1,3,4,26)$. 
The elevation in PVR in MAS was associated with a greater increase in plasma U-II than in controls, and blockade of U-II receptors with palosuran in MAS significantly attenuated the elevation of PVR. These findings suggest that U-II contributes to the increase in PVR in MAS. U-II has been described as the most potent vasoconstrictor yet identified, producing endothelial-independent constriction through its direct interaction with specific receptors on vascular smooth muscle (9). Vasoconstriction is said to predominate in situations where endothelial dysfunction and impaired production of vasodilators coexist, such as in pulmonary hypertension (27). A number of adult models of pulmonary hypertension have supported the contribution of U-II to this condition $(10,12)$. In addition, a recent study of rat pulmonary arteries (22) showed that pulmonary vasoconstrictor responses to U-II were potentiated by ET-1 and by hypoxia, which may partly explain the vasoconstrictor effects of U-II in our model of MAS in the presence of elevated ET-1 levels and arterial hypoxemia.

Our study suggests divergent roles for U-II in the perinatal transition such that under normal circumstances when U-II is relatively low, U-II-mediated vasodilation contributes to the fall in PVR. However, in the disease state, such as MAS, when it is likely that the U-II system is activated (28) and there is a greater increase in U-II, vasoconstriction may predominate. This hypothesis is partly supported by studies in rat aortic strips, where low concentrations of U-II caused transient relaxation, while higher concentrations caused sustained contraction (29).

A compelling analogy may be drawn between these observations and the properties of ET-1. Like U-II, ET-1 produces both endothelium-dependent vasodilation and endotheliumindependent vasoconstriction $(11,30)$ and plasma ET-1 levels are increased in the perinatal transitional circulation in some species (31). Although controversial, some investigators have proposed that ET-1-mediated vasodilation contributes to the changes in PVR during the early neonatal period (31). By contrast, in MAS, a heightened increase in ET-1 contributes to the genesis of pulmonary hypertension $(2,7,8)$.

Limitations. Our observation that palosuran abolished the fall in PVR led us to propose a primary, receptor-mediated role for U-II in the neonatal pulmonary vasodilator response. However, it must be acknowledged that administration of palosuran was associated with effects on blood gases, which could have contributed to the blunted pulmonary vasodilator response observed in the palosuran group. $\mathrm{Po}_{2}$ was slightly lower during the study period in this group than controls. We consider that this is unlikely to contribute to the blunted pulmonary vasodilator response, for a number of reasons: first, the differences were modest, $\mathrm{SaO}_{2}$ was well maintained; and second, in related models of the perinatal transitional circulation, neonatal pulmonary vasodilator responses occurred in the presence of much more extreme levels of hypoxemia $(30,32)$. Consideration also needs to be given to whether the differences in $\mathrm{pH}$ between control and palosuran animals contributed to the blunted response. Again, we do not consider that these differences have made a significant contribution, as changes in PVR occurred while $\mathrm{pH}$ in the palosuran group remained unchanged over the entire study period, and the major rise in PVR occurred early in the study, when $\mathrm{pH}$ was stable in both groups.

As the primary purpose of this article was to examine the pulmonary vascular effects of U-II, ventricular contractility was not directly measured. However, U-II is known to have both positive and negative inotropic effects $(9,11)$, therefore, it is possible that a negative inotropic or direct cardiotoxic effect of U-II antagonism in the normal perinatal circulation may have contributed to the systemic hemodynamic changes observed in palosuran treated controls.

Finally, it is important to note that our study was designed to examine the physiologic relevance of the endogenous U-II system in the perinatal circulation in the absence and presence of meconium aspiration. As a result, our experimental paradigm measured endogenous U-II, and the effects of a U-II receptor blocker, rather than the actions of exogenous infusions of U-II per se.

In conclusion, U-II, the recently characterized vasoactive peptide, appears to play a divergent role in the transitional circulation, contributing to the fall in PVR under normal circumstances, whereas producing pulmonary vasoconstriction during PHN secondary to MAS. Blockade of the U-II receptor with palosuran improves pulmonary hemodynamics in this model of MAS. Further studies are required to confirm our findings.

Acknowledgments. We thank Andrew Hattam and Magdy Sourial for assistance with experimental studies, Jonathan Mynard for developing our software, A/Prof Tim Yandle, Steve Fisher, and the Cardioendocrine Research Group, Christchurch, New Zealand, for performing the assays, and Dr Martine Clozel and Dr Marc Iglarz from Actelion Pharmaceuticals for supplying palosuran.

\section{REFERENCES}

1. Shekerdemian LS, Ravn HB, Penny DJ 2002 Intravenous sildenafil lowers pulmonary vascular resistance in a model of neonatal pulmonary hypertension. Am J Respir Crit Care Med 165:1098-1102

2. Shekerdemian LS, Penny DJ, Ryhammer PK, Reader JA, Ravn HB 2004 Endothelin-A receptor blockade and inhaled nitric oxide in a porcine model of meconium aspiration syndrome. Pediatr Res 56:353-358

3. Shekerdemian LS, Ravn HB, Penny DJ 2004 Interaction between inhaled nitric oxide and intravenous sildenafil in a porcine model of meconium aspiration syndrome. Pediatr Res 55:413-418

4. Davis PJ, Shekerdemian LS 2001 Meconium aspiration syndrome and extracorporeal membrane oxygenation. Arch Dis Child Fetal Neonatal Ed 84:F1-F3

5. Steinhorn RH, Morin FC III, Fineman JR 1997 Models of persistent pulmonary hypertension of the newborn (PPHN) and the role of cyclic guanosine monophosphate (GMP) in pulmonary vasorelaxation. Semin Perinatol 21:393-408

6. Haworth SG 2006 Pulmonary endothelium in the perinatal period. Pharmacol Rep 58:153-164

7. Kuo C, Chen J 1999 Effect of meconium aspiration on plasma endothelin-1 level and pulmonary hemodynamics in a piglet model. Biol Neonate 76:228-234

8. Kuo CY 2001 Endothelin-A receptor antagonist prevents neonatal pulmonary hypertension in meconium aspiration in piglets. J Formos Med Assoc 100:420-423

9. Ames RS, Sarau HM, Chambers JK, Willette RN, Aiyar NV, Romanic AM, Louden CS, Foley JJ, Sauermelch CF, Coatney RW, Ao Z, Disa J, Holmes SD, Stadel JM, Martin JD, Liu WS, Glover GI, Wilson S, McNulty DE, Ellis CE, Elshourbagy NA, Shabon U, Trill JJ, Hay DW, Ohlstein EH, Bergsma DJ, Douglas SA 1999 Human urotensin-II is a potent vasoconstrictor and agonist for the orphan receptor GPR14. Nature 401:282-286

10. Sun DJ, Yang JP, Sun YH 2006 [The expression and significance of urotensin II, nitric oxide, and C-type natriuretic peptide in hypoxia-induced pulmonary hypertension in rats.] Zhonghua Jie He He Hu Xi Za Zhi 29:185-188

11. Maguire JJ, Davenport AP 2002 Is urotensin-II the new endothelin? Br J Pharmacol 137:579-588 
12. Qi J, Du J, Tang X, Li J, Wei B, Tang C 2004 The upregulation of endothelial nitric oxide synthase and urotensin-II is associated with pulmonary hypertension and vascular diseases in rats produced by aortocaval shunting. Heart Vessels 19:81-88

13. Clozel M, Binkert C, Birker-Robaczewska M, Boukhadra C, Ding SS, Fischli W, Hess P, Mathys B, Morrison K, Muller C, Nayler O, Qiu C, Rey M, Scherz MW, Velker J, Weller T, Xi JF, Ziltener P 2004 Pharmacology of the urotensin-II receptor antagonist palosuran (ACT-058362; 1-[2-(4-benzyl-4-hydroxy-piperidin-1-yl)ethyl]-3-(2-methyl-quinolin-4-yl)-urea sulfate salt): first demonstration of a pathophysiological role of the urotensin System. J Pharmacol Exp Ther 311:204-212

14. Shiao SY, Ou CN 2007 Validation of oxygen saturation monitoring in neonates Am J Crit Care 16:168-178

15. Smolich JJ, Soust M, Berger PJ, Walker AM 1992 Indirect relation between rises in oxygen consumption and left ventricular output at birth in lambs. Circ Res 71:443450

16. Richards AM, Nicholls MG, Lainchbury JG, Fisher S, Yandle TG 2002 Plasma urotensin II in heart failure. Lancet 360:545-546

17. Kitamura K, Tanaka T, Kato J, Eto T, Tanaka K 1989 Regional distribution of immunoreactive endothelin in porcine tissue: abundance in inner medulla of kidney. Biochem Biophys Res Commun 161:348-352

18. Snedecor GW, Cochran WG 1980 Statistical Methods. The Iowa State University Press, Ames, Iowa, pp 350-352

19. Gibson A, Wallace P, Bern HA 1986 Cardiovascular effects of urotensin II in anesthetized and pithed rats. Gen Comp Endocrinol 64:435-439

20. Bottrill FE, Douglas SA, Hiley CR, White R 2000 Human urotensin-II is an endothelium-dependent vasodilator in rat small arteries. Br J Pharmacol 130:18651870

21. Gray GA, Jones MR, Sharif I 2001 Human urotensin II increases coronary perfusion pressure in the isolated rat heart: potentiation by nitric oxide synthase and cyclooxygenase inhibition. Life Sci 69:175-180

22. MacLean MR, Alexander D, Stirrat A, Gallagher M, Douglas SA, Ohlstein EH, Morecroft I, Polland K 2000 Contractile responses to human urotensin-II in rat and human pulmonary arteries: effect of endothelial factors and chronic hypoxia in the rat. Br J Pharmacol 130:201-204

23. Fox WW, Gewitz MH, Dinwiddie R, Drummond WH, Peckham GJ 1977 Pulmonary hypertension in the perinatal aspiration syndromes. Pediatrics 59:205-211

24. Cornish JD, Dreyer GL, Snyder GE, Kuehl TJ, Gerstmann DR, Null DM Jr, Coalson JJ, deLemos RA 1994 Failure of acute perinatal asphyxia or meconium aspiration to produce persistent pulmonary hypertension in a neonatal baboon model. Am J Obstet Gynecol 171:43-49

25. Wiswell TE, Gannon CM, Jacob J, Goldsmith L, Szyld E, Weiss K, Schutzman D, Cleary GM, Filipov P, Kurlat I, Caballero CL, Abassi S, Sprague D, Oltorf C, Padula M 2000 Delivery room management of the apparently vigorous meconium-stained neonate: results of the multicenter, international collaborative trial. Pediatrics 105:1-7

26. Durand M, Snyder JR, Gangitano E, Wu PY 1990 Oxygenation index in patients with meconium aspiration: conventional and extracorporeal membrane oxygenation therapy. Crit Care Med 18:373-377

27. Budhiraja R, Tuder RM, Hassoun PM 2004 Endothelial dysfunction in pulmonary hypertension. Circulation 109:159-165

28. Djordjevic T, Gorlach A 2007 Urotensin-II in the lung: a matter for vascular remodelling and pulmonary hypertension? Thromb Haemost 98:952-962

29. Gibson A 1987 Complex effects of Gillichthys urotensin II on rat aortic strips. Br J Pharmacol 91:205-212

30. Ivy DD, Lee DS, Rairigh RL, Parker TA, Abman SH 2004 Endothelin B receptor blockade attenuates pulmonary vasodilation in oxygen-ventilated fetal lambs. Biol Neonate 86:155-159

31. Levy M, Maurey C, Dinh-Xuan AT, Vouhe P, Israel-Biet D 2005 Developmental expression of vasoactive and growth factors in human lung. Role in pulmonary vascular resistance adaptation at birth. Pediatr Res 57:21R-25R

32. Cornfield DN, Chatfield BA, McQueston JA, McMurtry IF, Abman SH 1992 Effects of birth-related stimuli on L-arginine-dependent pulmonary vasodilation in ovine fetus. Am J Physiol 262:H1474-H1481 